\title{
Beyond Conflict and Competition
}

\author{
How Color-Blind Ideology Affects African Americans' \\ and Latinos' Understanding of Their Relationships
}

Chrisshonna Grant Nieva and Laura Pulido,

with Nathan J. Sessoms

$\mathrm{n}$ recent years, comparative ethnic studies has undergone a major renaissance. Increasingly, this work seeks to understand the experiences of multiple racial/ ethnic groups or illuminate processes within the larger racial formation. Within this literature, as well as in the larger society, the subject of Latina/o and African American relations has attracted considerable attention for several reasons. First, these two groups constitute the largest populations of color in the United States, with numerous implications. As historian Albert Camarillo has pointed out, seven of the ten largest cities are now minority-majority cities with important consequences for governance, representation, and social justice. ${ }^{1}$ Equally important is the fact that the growing Latina/o population may pose significant challenges to the current racial formation as it carves out a new racial position for itself. The contours of this new formation are still unclear, as are the implications for African Americans. Finally, the media have been instrumental in highlighting tensions. While certainly some conflict exists, it is unclear whether it has actually increased. What has increased, however, is the reportage of hostility. In her study of the Los Angeles Times, Grant Nieva found that 70

Crisshonna Grant Nieva is a lecturer in American studies and ethnicity at the University of Southern California. She earned a Ph.D. in American studies and ethnicity from the University of Southern California with a dissertation titled "This Is My Country: The Use of Blackness in Discourses of Racial Nativism towards Latino Immigrants."

Laura Pulido is a professor of American studies and ethnicity at the University of Southern California. Her books include Black, Brown, Yellow, and Left: Radical Activism in Los Angeles; A People's Guide to Los Angeles (with Laura Barraclough and Wendy Cheng); and Black and Brown in Los Angeles: Beyond Conflict and Coalition (co-edited with Josh Kun).

Nathan J. Sessoms holds a Ph.D. in geography from the University of Southern California and conducts research on effective programming and policy/systems change with respect to Black men and boys, as well as urban/suburban inter-ethnic relations and poverty and affluence concentration. An independent scholar, he also serves as the Vice President of Programs and Operations for the Los Angeles Brotherhood Crusade, an institution that works to provide resources, services, and a voice of advocacy to traditionally underserved communities. In 2013, the Leadership and Sustainability Institute for Black Male Achievement selected him as a Social Innovator.

Kalfou, Volume 1, Issue 1 (Spring 2014). (C) 2014 by the Regents of the University of California. ISSN 2151-4712 (print). ISSN 2372-0751 (online). http://dx.doi.org/10.15367/kf.v1i1.11. All rights reserved. 
percent of the articles on Latinas/os and African Americans were negative, thus giving the appearance of increased conflict. ${ }^{2}$

In this article, we examine the attitudes and experiences of Latinas/os and African Americans toward each other in the Los Angeles area. We found a range of attitudes and experiences on the part of interviewees, but we also found a clear pattern of respondents invoking color-blind ideology in their discussions of members of the other group. While other scholars have tackled the question of Black/Brown attitudes directly, few have done so within the context of critical race theory. ${ }^{3}$

Color-blind racism is a racial ideology that denies the existence of racism by emphasizing that we are all the same. In essence, color-blind racism does not "see" racism because of its supposed commitment to look beyond race. Most of what we know about color-blind racism has been developed within the context of a Black/white paradigm. While this makes sense given that the national racial narrative of the United States has been anchored along a Black/ white binary, it is also clear that this needs to expand, given the country's rapidly changing demographics. Thus the question becomes: To what extent have people of color adopted color-blind ideology-especially in relation to each other? Given that color blindness is a key part of the national racial formation, one would expect it to have some presence among people of color, but how exactly does it function? Does it do the same "work" that white color blindness performs with regard to Black people?

In this article, we explore how color-blind racism works among African Americans and Latinas/os in Los Angeles. Specifically, we focus on how race relations between Black and Latina/o Angelenos are described by both groups. While attentive to structural conditions impacting race relations, we discuss what sorts of ideologies on the micro-level (with macro-implications) are being used to make sense of these larger conditions and the social/personal experiences impacting race relations between both groups. How have Latinas/os and African Americans adopted, refuted, and negotiated mainstream ideologies of color-blind discourse in their understanding of interethnic relations?

\section{Black-Brown Relations}

There is a rapidly growing literature on Brown/Black relations, most of which is rooted in the larger literature on interethnic relations. Conceptually, two approaches dominate: the coalition and the competition models. In the first case, researchers have explored when and how Latinas/os and African Americans have been able to mobilize and build coalitions based on shared economic and/or political interests. ${ }^{4}$ This work has highlighted, in particular, the different structural conditions, historical moments, and political strategies that engender collaboration. Oftentimes, this work is rooted in a desire to identify the particularities of 
collaboration efforts (both successful and unsuccessful) in order to apply them to contemporary and future politics, as well as to challenge negative media representations.

In the second approach, scholars focus on the tensions between African Americans and Latinas/os. Demographic changes-particularly the increase in Latina/o immigration, economic and job competition, struggles over political representation, cultural and social differences, and material resources-are all factors associated with conflict between communities of color. ${ }^{5}$ Competition models highlight the struggles of living together in diverse neighborhoods with scarce resources. In turn, these material conditions, according to both conflict and competition theories, make it difficult for African Americans and Latinas/ os to manage peaceful interethnic relations. At times Black and Latina/o people are fighting for the same resources, described as a zero-sum conflict, while in other instances, they have distinct goals. ${ }^{6}$ More recent scholarship has indicated that both groups are hesitant to build coalitions with one another. Specifically, it is argued that African Americans are wary of building coalitions with Latinas/ os because of a desire to maintain control over their recent political gains and economic status. Conversely, there is growing evidence that Latinas/os are fearful of allying with African Americans because of anti-Black racism and a belief that their own numerical superiority makes coalition less beneficial to them. ${ }^{7}$

In addition to these two approaches, there is also a large body of work that examines the psychoanalytic side of Brown/Black relations-specifically stereotypes and attitudes. For example, research reveals that many African Americans see Latina/o immigration as a threat to their social, political, and economic status. They harbor antipathy toward the use of Spanish, and they are fearful that Latinas/os' immigration agenda will displace the unfinished work of the Civil Rights movement. Meanwhile, studies show that Latinas/os often view Black people as criminal, untrustworthy, aggressive, not hardworking, violent, and unintelligent. ${ }^{8}$ There is also resentment toward African Americans because of perceived benefits regarding citizenship and the idea that they share a similar culture and interests with whites. ${ }^{9}$

Overall, more research has explored African American attitudes toward Latinas/os than vice versa, and this is the case in Los Angeles. The few studies focused on Los Angeles Latinas/os support the general conclusions cited above, that many have negative views of Black people. However, a forthcoming study by Barreto, Gonzalez, and Sanchez found that Latinas/os in California and Los Angeles did not have strong feelings of competition with African Americans. This was especially true for immigrants. ${ }^{10}$ Although competition is a very specific attitude, this finding is important, as many researchers assume competition to be a key factor in hostile feelings and attitudes between groups. In terms of African American attitudes, several studies have found evidence that African Americans see Latinas/os as potential coalition partners, despite Black 
Angelenos reporting the greatest conflict with Latinas/os and vice versa. Specifically, Latinas/os were concerned about street crime while African Americans were more concerned about economic competition. Such findings of conflict and potential coalition, however, are not necessarily contradictory. Oliver and Mendelberg have suggested that African Americans simply don't see themselves in competition with whites because they are so removed from them, socially and spatially. ${ }^{11}$ In contrast, they are much more intimate with Latinas/ os, and thus more conflict is likely, as is the possibility of greater cooperation.

While Mark Sawyer's research revealed that, in general, African Americans' views toward unauthorized immigrants are largely the same as those of whites, it is possible that spatial proximity plays a role. For example, Frasure and Greene found that the more immigrants African Americans lived near, the less likely they were to favor amnesty. Thus, perhaps in the crowded spaces of South Los Angeles, there is a very real feeling of competition and that Latinas/ os are "taking over." This is a relevant finding because it contradicts Oliver and Wong's argument that the more mixing at the neighborhood level, the more tolerant and accepting people tended to be. Their data revealed that more racially isolated Latinas/os and African Americans tended to have the most negative attitudes toward each other. In addition to geography, class position has also been recognized as a key variable in determining attitudes. While many assume that middle-class African Americans are more likely to favor coalition with Latinas/os (as they are supposedly in less economic competition), Frasure and Greene found that low-income African Americans were more likely to oppose criminalizing unauthorized immigrants and more likely to support a guest-worker program than affluent Black Angelenos. Here it is possible that working-class African Americans' inability to escape the prison industrial complex has resulted in a more sympathetic attitude toward other potential "criminals." Collectively, these data suggest that there is no hard and fast rule regarding Black attitudes toward Latinas/os and immigration. Instead, there is a great deal of variation depending on many factors, including spatial proximity, perceived economic competition, and one's own economic security. ${ }^{12}$

Overall, these literatures help clarify the structural conditions that impact interethnic relations as well as illuminate specific attitudes and stereotypes. Nonetheless, this work has some limitations. With a few notable exceptions, much of this scholarship portrays Black-Brown relationships as static binaries, either positive or negative. In reality, there is a spectrum of relations and research to date does not adequately show the dynamic process by which relations are constructed, challenged, and negotiated. ${ }^{13}$ The static nature of the work can also be seen in the racial categories themselves. Far too often the categories of "Latino" and "African American" are treated as given entities, rather than as social processes in a constant state of becoming. Relatedly, the diversity of each group is not adequately considered; this is especially true in terms of 
Latinas/os and nativity, national origin, and generation. Much of the work on attitudes relies on quantitative and/or survey-based data that often limit participants' ability to express the range of opinions regarding a particular issue at a particular point in time. ${ }^{14}$

Drawing on critical race theory, several scholars have approached Brown/ Black relations as a process that is part of the larger racial formation. For example, Rochmes and Griffin have argued that a coalition between Latinas/os and African Americans is doubtful if Latinas/os are going to pursue whiteness, which is, in turn, based on the racial domination of African Americans. ${ }^{15}$ In their book on Mexican and Puerto Rican relations, De Genova and RamosZayas argued that intra-Latina/o relations cannot be understood outside of Blackness. They found that Mexicans often considered Puerto Ricans to be debased Black people, while Puerto Ricans considered Mexicans to be debased indios, both with extremely negative connotations. Building on these insights, Almaguer has argued that each group, as subjects of Spanish colonization and its attendant racial formations, has drawn on the subordinate racial categories within the Spanish-American empire. This kind of work is especially helpful because it enables us to see Brown/Black relations as fluid, socially constructed, and linked to a much larger set of power relations. ${ }^{16}$

\section{Color Blindness and Racial Formation}

Racial ideologies play a crucial role in the development of interethnic relations among people of color. These ideologies become the predictable models through which individuals understand race, as they are often hegemonic. Currently, colorblind ideology operates as one of the dominant racial logics in the United States. ${ }^{17}$ Critical race theory scholar Neil Gotanda has argued that although color-blind constitutionalism rhetoric existed before the Civil War, the "modern concept" of color blindness developed in the post-Civil Rights era. ${ }^{18}$ After Brown vs. Board of Education and the other victories of the Civil Rights movement, a new ideology was needed to maintain white supremacy. Because overt forms of racism (individual and institutional) were no longer legally acceptable, whites developed a new mechanism to support white privilege. Eduardo Bonilla-Silva argues that as "much as Jim Crow racism served as the glue for defending a brutal and overt system of racial oppression in the pre-Civil Rights era, color-blind racism serves today as the ideological armor for a covert and institutionalized system in the post-Civil Rights era." ${ }^{\prime 19}$

Bonilla-Silva has articulated four frames of color-blind racism that Americans routinely use to explain racial inequality without considering larger structural forces. Abstract liberalism refers to attempts to explain racial inequality by combining political-liberal notions, such as equal opportunity, with economic-liberal notions of free choice and/or individualism. Naturalism involves 
interpreting racial inequality as a natural or inevitable experience, while cultural racism argues that culture determines existing racial stratification. Finally, minimization discounts the existence and significance of racism. ${ }^{20}$ In addition to Bonilla-Silva's four frames, we also draw upon Kimberlé Crenshaw, who argues that ahistoricism is central to the development and deployment of a color-blind ideology. Crenshaw argues that through the "willful inattention to the historical operations of white supremacy, contemporary race hierarchy is ... represented as a natural outgrowth of cultural disability and economic dependence." ${ }^{21}$ Collectively, these ideologies have negative social and material consequences for subordinated racial/ethnic groups because they preclude challenging the racial hierarchy and operate to support white supremacy.

Doane argues, "It is not necessary that the 'color-blind' discourse be universal . . but merely influential enough to neutralize or redirect potential challenges of the existing racial order."22 Color-blind racism promotes a discourse of "freedom" and "equality" that suggests state and government intervention is a hindrance to the natural process of the marketplace that, allegedly, fairly disperses resources and opportunities based on merit. In this scenario, any attempt to highlight structural and/or individual racism is dismissed as "playing the race card." Because the marginalization and disenfranchisement of people of color are explained as individual and/or group failures-instead of systematic discrimination - there is no need, supposedly, to work against a dominant social system in which white people are favored.

While color-blind theories have been crucial to our understanding of the present racial formation, ${ }^{23}$ few scholars working in this framework have applied it directly to communities of color. More often, color-blind racism has been used to describe how the state and economic and social institutions have supported discriminatory policies and/or how white individuals use color-blind ideology. While people of color's use of color-blind ideology may vary from that of whites in terms of degree, nature, and logic, people of color are nevertheless subject to its influences as members of society. Certainly, one could argue that people of color's material experiences may lead to alternative racial ideologies, ${ }^{24}$ but it is also true that they must negotiate the racial "common sense" that circulates.

\section{The Contemporary Landscape of Latinas/os and African Americans in Southern California}

In order to fully understand the complex relations between African Americans and Latinas/os, we must first get a sense of the history, demographics, geography, and economic positions that characterize each group. Although many point with pride to the fact that the first nonindigenous settlers of Los Angeles were multiracial, in fact, for most of Los Angeles' history, Black and Mexican communities have developed along distinct trajectories with occasional points of 
Table 1. Growth in the Black and Latino Populations of Los Angeles County, 1940-2000

\begin{tabular}{|r|r|r|r|r|}
\hline Year & $\begin{array}{r}\text { African } \\
\text { Americans }\end{array}$ & Percentage & Latinos & Percentage \\
\hline 1940 & 75,206 & 2.60 & 61,248 & 2.00 \\
\hline 1950 & 214,897 & 5.00 & 249,173 & 5.70 \\
\hline 1960 & 459,806 & 7.50 & 582,309 & 9.60 \\
\hline 1970 & 755,719 & 10.70 & $1,288,716$ & 18.30 \\
\hline 1980 & 924,774 & 12.30 & $2,071,530$ & 27.50 \\
\hline 1990 & 931,449 & 10.46 & $3,359,526$ & 38.00 \\
\hline 2000 & 930,957 & 9.50 & $4,242,213$ & 45.00 \\
\hline 2005 & 883,911 & 9.20 & $4,658,878$ & 47.10 \\
\hline
\end{tabular}

Sources: Phil Ethington, “Total Population, Showing Ethnic Composition, Los Angeles County, 1940-1960," in Segregated Diversity: Race-Ethnicity, Space and Political Fragmentation in Los Angeles County, 1940-1994, Final Report to the John Randolph Haynes and Dora Haynes Foundation, July 2000, 12; United Way, 2003 State of the County Report (Los Angeles: United Way of Greater Los Angeles, 2003), 32; American Community Survey, Demographic and Housing Estimates, Los Angeles County, 2005-2007; US Census Bureau, Geographic Comparison Table, Los Angeles County, 2000.

contact. ${ }^{25}$ Both were attracted to the region because of economic opportunity as well as the desire to flee revolutionary Mexico and the racial terror of the Jim Crow South. By 1920, there was a sizable population of each racial/ethnic group.

Both groups underwent considerable change during the World War II era. The African American population was radically transformed by the thousands of Black migrants who were lured by the wartime economy. This influx raised concern among some long-standing Black Angelenos, who felt that these newcomers-who were perceived as rural and "backwards"-would reflect poorly on them and potentially jeopardize the hard-fought gains of the Black community. ${ }^{26}$ For Mexican Americans, wartime labor shortages enabled them to enter the formal economy and labor unions in unprecedented numbers. This set the stage for the economic incorporation of Mexican Americans, albeit in a subordinated status.

By 1970, the two populations were roughly comparable in size, economic status, and educational attainment. Latinos/as tended to live in East Los Angeles, while Black people were concentrated in South Los Angeles (Figures 1 and 2). The demographic landscape changed abruptly in the 1980s, however, with accelerated immigration from Mexico and, increasingly, Central America. Due to changes in immigration laws, the Mexican debt crisis, Central American political strife, and the US economy's insatiable appetite for cheap labor, Southern California was radically transformed by Latina/o and, to a lesser extent, Asian immigration. By 2000, Latinos comprised 45 percent of Los Angeles County's population, while African Americans were 9 percent and dropping. Despite the resulting differences in size, the percentage of Black and Brown people living in poverty in 2005 was nearly identical: 20.4 percent and 21.1 percent, respectively. ${ }^{27}$ While Black wages 

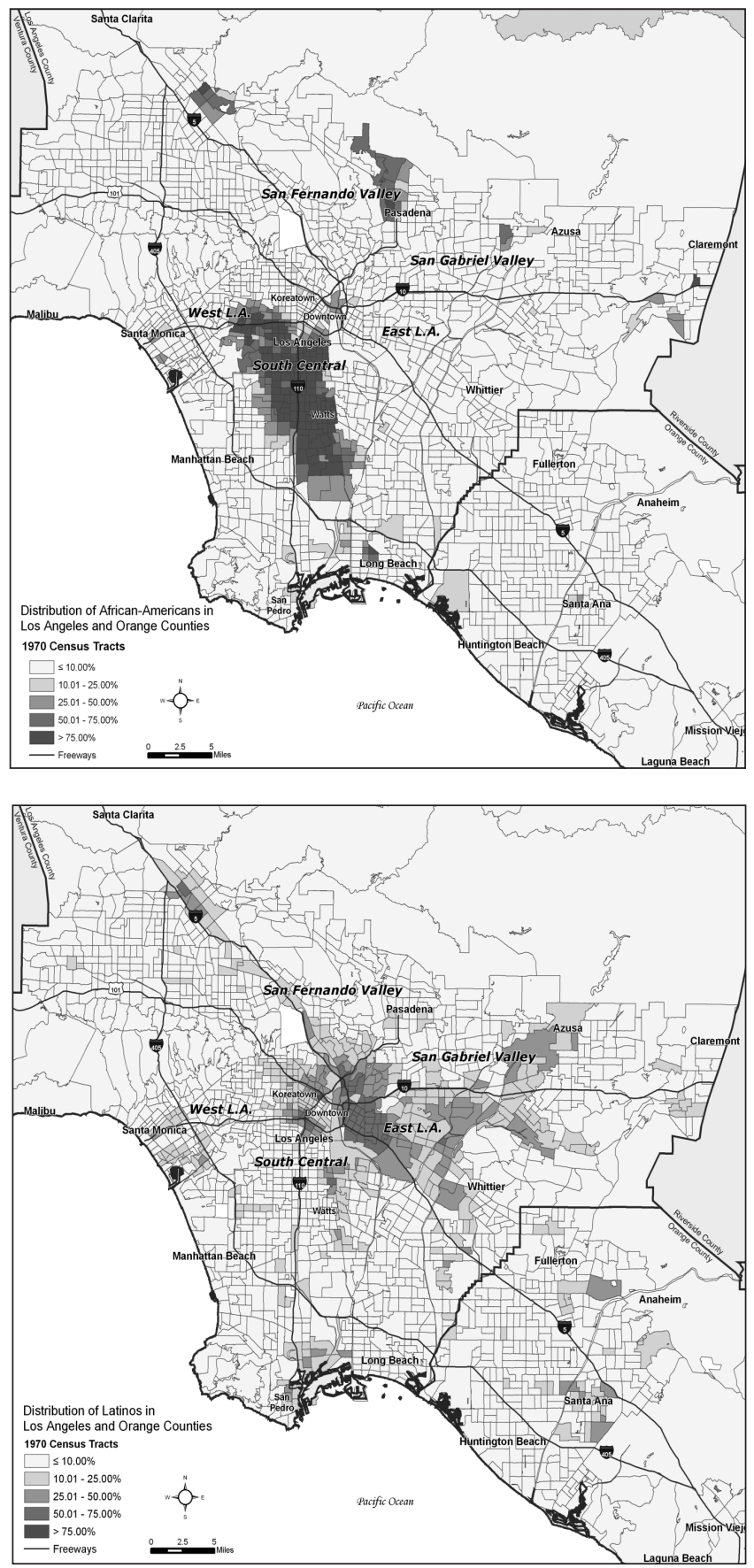

Figure 1. Distribution of African Americans and Latinas/os in Los Angeles and Orange Counties, 1970. 

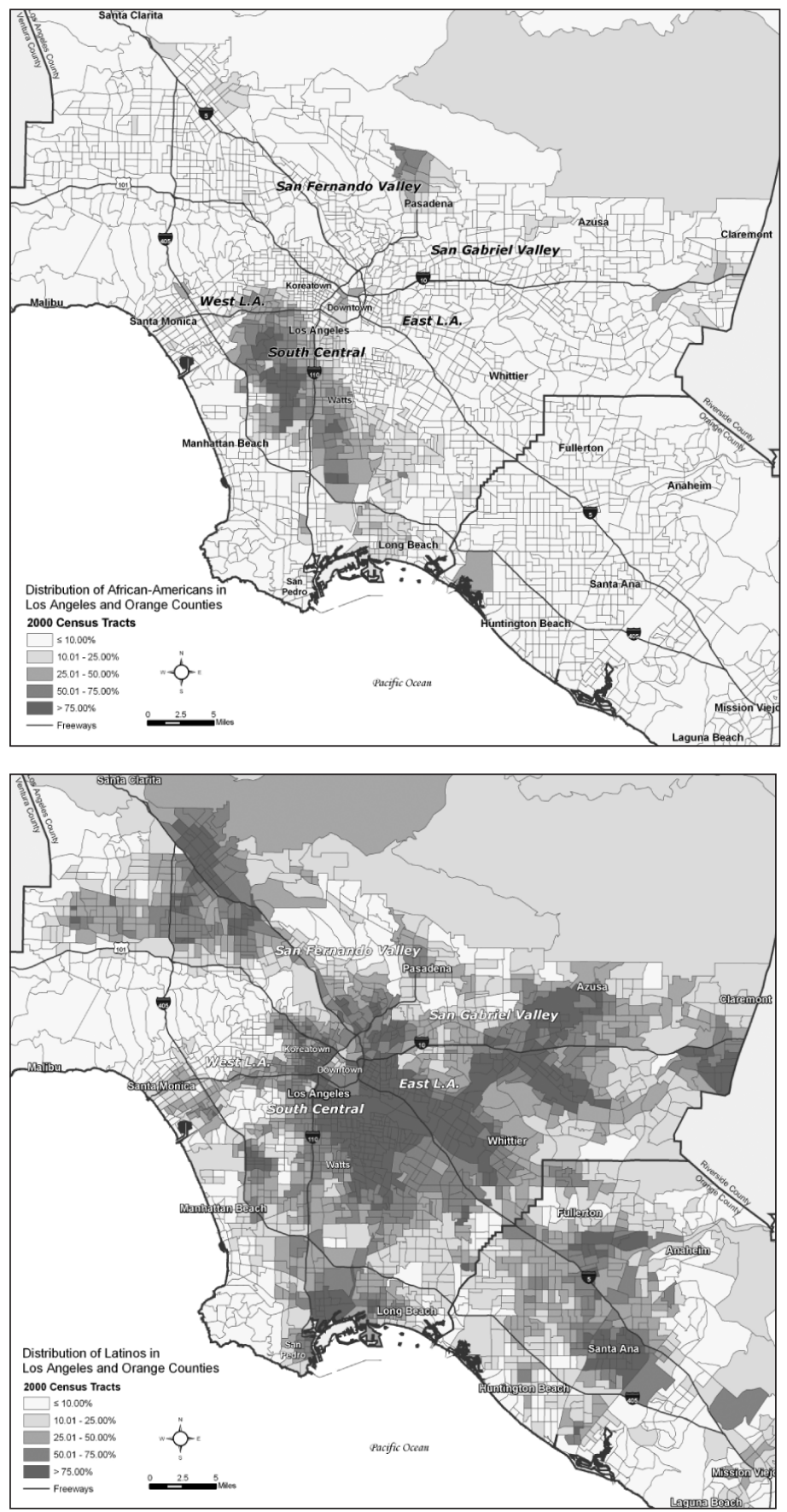

Figure 2. Distribution of African Americans and Latinas/os

in Los Angeles and Orange Counties, 2000. 
are significantly higher than Latina/os' (\$17.51 per hour versus $\$ 11.50$ ) on average, these figures mask the fact that among low-income households, Latinas/os have higher earnings than African Americans. This is because Latinas/os work more than their Black counterparts, who find it harder to secure employment. ${ }^{28}$

This, in turn, reflects larger differences in economic participation. African Americans typically have had higher unemployment rates and have been more closely associated with public sector employment, while Latinas/os have slightly lower unemployment rates and are more likely to work in the private sector. ${ }^{29}$ While many assume that Latinas/os have simply displaced African American workers, the reality is more complicated. In a few sectors, there has been significant displacement. The most oft-cited example is the janitorial industry: as older, Black, unionized janitors retired, they were replaced by nonunion immigrant Latinas/os. ${ }^{30}$ In other sectors, however, the influx of immigrant workers has enhanced the economic position of African Americans, as they have the requisite language and cultural capacity to assume supervisory or management positions. While this shift has benefited educated and skilled Black workers, this is not the case for the less-skilled. ${ }^{31}$

These racialized outcomes can be traced not only to historic patterns, but also to contemporary economic restructuring. While both groups may be considered surplus labor, they experience this in different ways. Indeed, as far back as the 1960s, before the massive immigration influx, Mexican Americans were more deeply attached to the manufacturing economy and unionization than African Americans. ${ }^{32}$ Since the deindustrialization of the 1980 s and the arrival of millions of immigrants, African American unemployment has been exacerbated by additional factors. First, as citizens, not only are Black workers less willing to tolerate high rates of exploitation, but they-particularly Black males-are also seen as less desirable workers. Indeed, several studies have documented employer discrimination against African Americans, who are found to be wanting in comparison to immigrants. Of course, for capital, immigrants are the ultimate surplus labor force as they can be deported and otherwise regulated out of the job market.

The second factor in African Americans' labor market exclusion is employer reliance on immigrant networks. Building on their preference for immigrants, employers increasingly rely on immigrants' networks to provide additional workers, which usually excludes both native-born Latinas/os and African Americans. ${ }^{33}$ Thus, when people state that immigrants "take" jobs from African Americans, there is some truth to it, but it ignores several key facts, such as: Latinas/os and African Americans have historically held distinct places in the regional economy; native-born Latinas/os, not Black workers, are in the greatest competition with immigrants; there is a very long history of employers discriminating against African Americans, which has little to do with Latinas/os; and it is primarily less-educated and less-skilled African Americans who are negatively affected by Latina/o immigrant workers. 
Two additional developments further shaped the social and economic landscape for people of color in Los Angeles. As previously mentioned, in the 1980s the region lost its older manufacturing base, and with it the ladder to the middle class. Since then, Angelenos have found employment in the growing service sector, and to a lesser extent, in a restructured manufacturing sector featuring lower wages and greater instability than the previous industrial formation. ${ }^{34}$ This new economic structure is characterized by a polarized income distribution, leading Los Angeles County to emerge as the US capital of the working poor. ${ }^{35}$ Second, in the 1980s the state of California began a massive prison expansion project that devoured vast numbers of colored bodies, especially Black surplus labor. ${ }^{36}$ Not only does incarceration take away potential wage-earners, but it severely reduces their future earning potential upon their release. This has had devastating consequences for local communities. Coupled with growing economic polarization, it has left traditional Black and Brown spaces, such as East LA and South Central, deeply impoverished places.

As a result of all these shifts, the residential geography of Southern California has changed considerably. Figures 1 and 2 show the distribution of Latinas/ os and African Americans in Los Angeles in 1970 and 2000. Several changes can be discerned. First, and most obvious, is the tremendous expansion of the Latina/o population. Whereas Latinos used to be concentrated in a few areas, such as East LA and the eastern San Fernando Valley, they are now everywhere, in many cases comprising the dominant ethnic group. Nonetheless, a clear eastward trajectory is apparent, as Latinas/os, both immigrant and nativeborn, have increasingly moved into the Inland Empire and northern parts of Los Angeles County.

African Americans have also undergone significant spatial changes. Beginning in the 1970s as residential discrimination diminished, members of the Black middle class began leaving South Central. They first moved west, to such neighborhoods as Baldwin Hills. Then, in the '80s and '90s, many workingclass African Americans moved both to the Inland Empire and northward in search of affordable housing, safer neighborhoods, and better schools.$^{37}$ It is precisely into these spaces vacated by African Americans that many Latina/o immigrants moved.

Such residential shifts have been met with a range of reactions. One concern of African Americans is electoral. There are now few, if any, "safe" Black seats. Whereas Black Angelenos used to be advantaged in terms of political leaders, it is now Latinas/os who are. A second important change is the landscape itself. South Central Los Angeles, which has long been identified as a Black space, is now 50 percent Latina/o. As the signage, commerce, sounds, and feel of the neighborhood have changed, this has also generated a range of responses, particularly on the part of African Americans, some of whom mourn the loss of a Black space. 


\section{Methodology}

The data for this study were collected between 2003 and 2004. Working with a team of graduate students, we identified (through the snowball method) both African Americans and Latinas/os over 18 years of age living in Southern California and conducted seventy-three interviews. The interviewees were roughly divided between African Americans and Latinas/os, with less than a handful of people identifying as Afro-Latino. We conducted semi-structured interviews that lasted anywhere from thirty minutes to two hours, but averaged one hour.

Each interview started with a series of questions regarding the interviewee's background and personal history, and then moved toward questions focused on his or her previous experience and contacts with members of the other racial/ethnic group. In this section, considerable attention was paid to personal geographies, such as the racial/ethnic composition of neighborhoods and schools. The final set of questions explored respondents' attitudes and perceptions toward the other group, and why and how those views might have developed. All interviews were transcribed and analyzed for major themes.

\section{Latina/o and African American Perceptions of Each Other}

One of our most important findings is that there is not one set of relationships between African Americans and Latinas/os. Instead, we found patterns that varied by nativity, age, geography, class, and national origin. For example, while many Latinas/os voiced negative stereotypes about African Americans, in general, native-born Latinas/os tended to know more about them and have more positive assessments, but it was also true that many native-born Latinas/ os, especially those living in the greater San Gabriel Valley or Orange County, had relatively little contact with African Americans. ${ }^{38}$ Immigrants, on the other hand, tended to have much more interaction, as they were often sharing the same space, namely South Central. Indeed, Latina/o immigrants initially received negative portrayals of African Americans from contacts who had traveled to the United States and returned to share their stories, as well as from US media, which regularly portray Black Americans as criminal and lazy. National origin was also significant. While the vast majority of Latina/o interviewees were ethnic Mexicans, the few Cubans and South American respondents we had stood out as having much more critical views toward African Americans. Finally, there were clear differences in terms of status and education. While the vast majority of African Americans exhibited fairly positive attitudes toward Latinas/os, college-educated Black people were much more likely not to see Latinas/os as competitors and to entertain the possibility of coalition.

Another important finding was the extent to which Black interviewees saw Latinas/os as a monolithic immigrant group and as non-English-speaking resi- 
dents. The vast majority of Black respondents was seemingly oblivious to the long presence of Latinas/os, especially Mexicans, in Los Angeles, and saw the group entirely as recent arrivals. ${ }^{39}$ Likewise, there was no acknowledgment that Southern California was once part of Mexico. Latinas/os were also unaware of the history of Black Los Angeles, but to a lesser extent. While most Latinas/os had some awareness of US slavery, the Civil Rights movement, and such figures as Martin Luther King Jr., most contended that the effects of slavery had long subsided. It is important to note, however, that both Latinas/os and African Americans with more education and/or a higher socioeconomic position were more knowledgeable about Black and Latina/o social, political, and economic struggles (both in the past and present), and consequently were more critical of racism and classism. While the role of education is certainly important (and underscores the need for rigorous ethnic studies in K-12), it is also essential to realize that for low-income Black residents living, for example, in South Central, the vast majority of Latinas/ os they encounter are immigrants. In contrast, professional African Americans are much more likely to encounter native-born Latinas/os in the workplace and institutions of higher education. Thus, these patterns are not simply a function of schooling, but also reflect real-life experiences.

Despite the general consensus that life was materially and socially hard, many interviewees insisted that we live in a meritocracy where hard work was rewarded. Although there were some who challenged this view, the overall trend was consistent. Interestingly, this sentiment was voiced most fervently among the most disenfranchised-Black working-class residents and Latina/o immigrants.

We now examine more closely how interviewees used color-blind rhetoric to discuss Brown/Black race relations. Why is it that Latinas/os are seen as hardworking while Black folks are seen as lazy? What role does the lack of historical racial knowledge play in the development and deployment of a colorblind ideology? What are the implications for white supremacy?

\section{Latinas/os' Use of Color-Blind Racism}

Latinas/os employed multiple frames of color-blind racism to describe their racial position and their relationships with African Americans. In addition to those who simply stated that they did not "see race," we found that Latinas/os routinely employed the frames identified by Bonilla-Silva and Crenshaw: minimization of discrimination, abstract liberalism, cultural racism, and ahistoricism.

\section{"Race Card" Abusers versus Ambitious Hard Workers}

One of the most prominent ways that color-blind ideology manifested itself among Latina/o interviewees was through the "race card" argument, which combines a minimization of discrimination with abstract liberalism. The 
"race card" argument is a mainstream position used to invalidate Black claims of injury by asserting that African Americans do not face structural inequalities, and instead, frequently and unfairly use their racial position to claim victim status. This argument is one of the most common ways that discrimination is minimized and has an underlying allegiance to abstract liberalism, as it confirms that the United States offers equal opportunity to all regardless of race.

The "race card" argument was most frequently applied to the belief that African Americans are unwilling to work hard. Interviewees asserted (to varying degrees) that Black Angelenos were reluctant to work hard, but they felt that African Americans sought excuses in unsubstantiated claims of discrimination. Statements like "They always use their color" and "Blacks sometimes feel like everything is owed to them. . . . [T] hey have that mentality like, 'We were slaves and now we should be repaid for it" are illustrations of how structural discrimination against Black Angelenos is dismissed in a narrative that presumes that they prefer to cry racism rather than "work hard." Aside from a commitment to individual choice and a belief in an equitable society, the refusal to acknowledge racism is predicated on ahistoricism: if one does not appreciate the power of the past, it is, in fact, relatively easy to ignore contemporary discrimination as well as the legacy of structural inequality. Many Latina/o respondents had narrow understandings of slavery and its ramifications in the United States or Latin America. ${ }^{40}$ Slavery was perceived as an event/period with a clear beginning and end and devoid of long-term consequences. For example, slavery was completely unattached to Jim Crow or racial violence. Because slavery no longer formally exists, Latinas/os reasoned that African Americans were exploiting past injustices to avoid responsibility for their own problems. The contemporary struggles of Black Americans were viewed as detached from any historical connection to the past. This perspective is especially powerful coming from people of color and immigrants. White adherents to a color-blind ideology routinely claim, "I did not participate in slavery," in order to show that they are not complicit in Black subordination. Scholars, of course, have pointed out how one need not have been a slave-owner to reap the benefits of white supremacy and domination. Yet the case of immigrants of color is more complicated as it requires us to explore the murky terrain of how people of color-in this case, Latinas/os - may have benefited from Black subordination, often by claiming whiteness. ${ }^{41}$ In addition, it necessitates that we expand our scale of analysis to consider the global implications of anti-Black racism and how it functions across the world.

In another twist, some Latinas/os, especially immigrants, juxtaposed their situation to that of African Americans. "Martha," a 50-year-old Cuban immigrant, critiqued African Americans' work ethic by highlighting Cubans' success: 
[Blacks] live in poverty if [they] want to live in poverty.... I always look to the Cuban community. . . . For instance, we came to the United States with not even a penny in our pockets, and most of us ... have [made] something of ourselves.... I don't want to live having to rob in order to survive. There's work in the United States if you want to work.

This quote raises a number of important issues that need to be unpacked. First, she compares the situation of Cuban immigrants and African Americans as if they were comparable. Such a move is predicated on forgetting two critical histories: first, the long history of Black racial subordination, and second, the special treatment given to Cuban immigrants because they fled a Communist regime. Although it is always problematic to compare immigrant and nativeborn groups, it is especially so with Cubans. The immigrant analogy is common among conservative narratives of social inequality, in which African Americans are routinely found wanting. But the same argument employed by persons considered to be nonwhite serves as an active reinforcement of white supremacy by suggesting that if some nonwhites can achieve economic success, personal failure is the only reason for Black inequality. ${ }^{42}$ Second, the quote foregrounds the criminalization of African Americans. Martha implies that there is ample and accessible employment in the formal economy. Consequently, if African Americans choose not to avail themselves of such opportunities, the inevitable conclusion is a life of crime. This is quite a leap, but clearly she is able to do so given larger discourses of Black criminality.

The racialization of African Americans as lazy juxtaposed to Latinas/os as hardworking was a continuous theme. It is critical to understand that one cannot exist without the other. Latinas/os must be especially hardworking in comparison to someone and African Americans must be relatively less so compared to someone. The following quote from Selena, a middle-aged Mexican who came to Los Angeles as a toddler, illustrates this:

The Black, in my eyes, is lazy and feel[s] that we owe them a job.... If their nature is not to work and sweat, then they are not going to get that position. The Latino is hungry.... [African Americans] think of their color as an obstacle to getting ahead. "I'm not going to get this job because I'm Black ..." But yet, can this person work as fast and accurate? They don't look at that. ... That's the only reason I say that they are lazy. They want everything handed to them.... They have to work just as hard as we do.

Clearly, a large number of Latinas/os have embraced the "Latinas/os as hard workers" ideology. ${ }^{43}$ We must be attentive to the context that engenders such beliefs. In a society where Latina/o immigrants are regularly demonized and subject to intense forms of state violence, ${ }^{44}$ their work ethic is the one positive 
attribute that the larger public has conceded. Given their desire to have their rights as humans and workers respected, it is hardly surprising that Latinas/os would claim it, but it also leads to numerous political and economic problems. Aside from contributing to the subordination of African Americans, it also leads to the greater exploitation of Latina/o workers, as they are commonly seen as disposable labor. Finally, we must be cognizant of the silence of whiteness and capitalism in all of these narratives. Almost no interviewees mentioned how others, primarily whites and capitalists of all colors, benefited from these racializations by ensuring a pool of low-wage and surplus labor.

\section{Race Is Not an Issue}

A final way that Latina/o interviewees adhered to color-blind racism was by flatly stating that they "don't see race," or that race is simply an empty category. These assertions were often linked, however, to stereotypical claims about Black Angelenos. For instance, Daniel, a 37-year-old biracial (Black/Latino) Southern California native, described his dating preferences by explaining that he sees the person, rather than a color:

I am an equal opportunity dater.... As long as the person is cool and fits with the kind of person that I am, I'll go out with them, it doesn't matter. . . . I don't think I stayed away from any ethnicity until I got older and learned a few things.... I have noticed that Black women ... have much more of an attitude, and I don't deal very well with people who have attitudes.... I mean everyone has an attitude, but because of situations that people have been in, in certain ethnic groups, some people hold on to them, latch on to them and use them as excuses. And unfortunately, a lot of African American women tend to be that way. It's unfortunate, but that's just the way it is.

Daniel began by promoting a color-blind dating preference and then he explained how Black women were different. He did not see his arguments as prejudice, but rather believed he was highlighting a "fact," which his experience proved. Daniel's desire to be seen as non-judgmental and non-discriminatory is a prominent trope in color-blind ideology. ${ }^{45}$ Adriana likewise insisted that she was color-blind. Adriana explained that she could not see race, and even argued that people who stereotype others are ignorant.

Adriana: I try not to make race an issue; it's more about the actual person...

INTERVIEWER: How do you think people in general perceive Black people? 
ADriAnA: Lazy, useless?

INTERVIEWER: Do you think there might be a reason for people viewing them in this manner?

Adriana: Maybe because they had a bad experience with them. There are people like that who have one bad experience with one person and then blame it on everyone else. These are ignorant people. These are people who are not educated.

By trying "not to make race an issue" and claiming to be "an equal opportunity dater" both interviewees are positioning themselves as non-racists. This is an essential step in the construction of a color-blind ideology. As Neil Gotanda has observed, one must first stake out a moral position, disavow race, and then proceed to observe racial differences. ${ }^{46}$ What is especially important (and dangerous) is the extent to which David and Adriana believe they are free of prejudice. Disavowing personal prejudice and racism is essential in a neoliberal meritocracy because only individuals are thought to harbor prejudice and racism, not institutions or market forces.

\section{Black Angelenos' Use of Color-Blind Racism}

In a manner similar to the Latina/o interviewees, African Americans also adhered to a color-blind rhetoric. This was apparent in how they explained their own social conditions, which included constructing Latinas/os as hard workers while emphasizing a collective Black laziness. In addition, they minimized discrimination. Many African Americans asserted that racism was no longer problematic, or at least as problematic, as it was in the past. Thus, through the use of cultural racism, abstract liberalism, and the minimization of discrimination, Black interviewees voiced a color-blind ideology when describing their perceptions of and relationships to Latinas/os.

\section{Latinas/os Are Going to Work Regardless}

In his interviews with African Americans, Bonilla-Silva argued that although they did not completely buy into cultural racism, color-blind ideology indirectly impacted how they interpreted their conditions. Specifically, he found that over a third of his respondents believed in the stereotypes of Black people as lazy and welfare dependent. ${ }^{47}$ Our findings echo Bonilla-Silva's, but instead of African Americans comparing themselves to whites, Black Angelenos compared themselves to Latinas/os. When discussing their social position(s), African Americans often articulated negative stereotypes of themselves while viewing Latinas/os as hard workers. Part of the hardworking Latina/o narrative was an acknowledgment that they were willing to work for any price. 
According to Bernard, an 80-year-old African American man born in the South:

Latinos are going to work ... regardless of what the price is. All they want to know is if they have a job. Where if Latinos work for three dollars an hour, the Blacks are not going to work for that. [They] feel that that is not enough money. The Latinos . . . know in their country that [they can't get] $\$ 2$ and something an hour. They ... will eat beans for a whole month. See, Black people won't work for a certain amount of money because they feel like that is not enough money. All Latinas/os need is a chance and an opportunity. That's why a lot of them come over here. Black people ain't going to work for a dollar and a half an hour. If he do, he gonna drag around . . . and have an attitude. The Latino is gonna show up to work on time and you can depend on him.

This quote reveals a great deal about the racialized nature of work and class politics in Southern California and the larger United States. First, as suggested earlier, Bernard applauds the fact that Latinas/os will work for low wages without considering its impact on the larger working class, or, more importantly, why they would do such a thing (aside from the pay disparity). He ignores the fact that it is not all Latinas/os who do this, but immigrants-recent immigrants, at that. Collapsing the immigrant/native distinction is extremely common when discussing Latinas/os. Relatedly, he overlooks the power of employers, who are highly cognizant of the vulnerable position of immigrant Latinas/os, especially the undocumented, and exploit them via extremely low wages, harsh working conditions, and even the withholding of pay. Another major problem with Bernard's conceptualization of the situation is the way he portrays African Americans as feeling entitled, perhaps inappropriately so, to a higher wage. ${ }^{48}$ It must be pointed out that it is not simply African Americans but all native-born persons, including Latinas/os, who refuse to work for three dollars per hour. The real question is why is it that African Americans get singled out for a scolding when, in fact, this attitude is universal among the native-born? A second issue that Bernard does not mention is labor exploitation and employment discrimination and how they might contribute to Black workers' unwillingness to accept poor pay. Instead, he insinuates that they lack Latinas/os' work ethic. There is also no acknowledgment of African Americans' long history of labor organizing and the struggle for a livable wage and decent working conditions. ${ }^{49}$ Consequently, only African Americans are condemned for not accepting inequitable pay. The power of color-blind ideology is profound when we consider the extent to which African Americans have internalized it. 
Other Black interviewees saw Latinas/os as visionaries, responsible workers, and a group that provides for their families:

I think that [Latinos] take care of business; even if they're on the freeway selling oranges, they're trying to make a better life for themselves. I think they take a lot of pride in their culture. . . . [T]hey take care of their families; I would always see them in a car, like packed 10 in a Honda.... They're all goin' to the same place.

-Imani, 19-year-old Black South Los Angeles native

[Latinos] appear to be very intelligent and able to plan. They may be selling oranges on the corner but that is part of a plan to then go on to do something bigger and better. Whereas Black people seem to be somewhat complacent. We are kind of watching them and making fun of them as they build and create.

-Jarvis, native Angeleno in her thirties

Numerous interviewees referred to selling oranges, as this is considered to be one of the lowest economic positions in the region (an illegal activity, at that). Yet both Imani and Jarvis see this in a positive light-albeit one that casts a negative light on Black Angelenos.

Implicit in these quotes is the belief that African Americans do not possess the same worthy characteristics that Latinas/os do. Focusing on cultural "attributes" of success, the larger conditions are ignored.

For other Black interviewees, the power to change social conditions is firmly rooted in the individual. Darryl was born in the South during the '60s, and viewed Latinas/os as opportunists:

[A] lot of people complain about the minorities coming over and opening their own businesses. ... I believe it's because Latinos are, as they ... say, more hungry for it. They find the information . . . and they follow through . . . as opposed to some of the African Americans. They talk about ... government programs, grants, loans, business; all this stuff is free but no one wants to do the time, but when [Blacks] see another store open up, and it's [another] minority, it's like, "Hello, you could have done the same thing," so basically it seem[s] that [Latinos] are just following through with more. ... I think one is just more aggressive than the other. ... [Latinas/os] are doing what they want to do. ... And the ones who are aggressive are the ones succeeding and the ones who are just whining are the ones who are not. ... And you know we can all complain about this and that, and blame other people for our problems but it's up to us as individuals to get out and make that change. 
Again, we are revisited by a belief that Black Angelenos simply complain (as we saw in the "race card" narrative among the Latina/o interviewees), while overlooking the centuries-long battle that African Americans have waged to create a more socially just society.

\section{We're Not Struggling Anymore}

In addition to coupling abstract liberalistic notions with cultural racism, Black Angelenos also minimized discrimination when discussing Black and Brown social positions. Imani, whom we met above, suggested that both groups should get along because they are no longer competing for resources, as we live in a society where opportunity exists for both:

We're [Blacks and Latinos] out to get things done and have a better opportunity in life or whatever. And we should be united, there's no reason for us to not get along anymore, we're not struggling anymore, there are opportunities out there for both of us.

For Imani, racial conflict should not exist where sufficient opportunities exist. Her "anymore" suggests that earlier opportunities were limited for African Americans and Latinas/os, and conflict may have been understandable, but not now. Accordingly, there is no need to challenge the racial order in the United States.

Camille, a 40-year-old Black woman born in the South, emphasized that individuals bear the sole responsibility for their success. Based on her personal experience, she saw racism as a way to make people believe that they could not achieve success. For Camille, it was not about structural discrimination but rather a mental oppression. Thus, the key to overcoming racism is the realization of individual potential:

No, it's personality, when somebody uses that [race as an explanation for social conditions] it's nothing but an old cop-out. They just don't want to admit that they have a rotten personality. When I was out in the world, you could not get me to look in the mirror at myself. I got this sponsor who got me to look in the mirror and love myself. I just couldn't do it. I used that old jargon, "It's the white man keeping me down" or "It's the Mexicans taking all of the jobs." That was a lie. It was I. Once I realized that, I was able to get it together. Once I realized that, I was set free. The reason why racism was such a big thing in the South was because they knew we were more, they knew we were intelligent. They knew we had to strive harder to know more. ... That's what I believe.... We use it as a scapegoat. 
Camille exemplifies the primary way that Black Angelenos articulated color blindness. It was not so much in what they said about Latinas/os, but in how they saw the larger racial formation. Color blindness was manifest in African Americans' commitment to the tropes identified by Bonilla-Silva and Crenshaw, which collectively discounted the existence of racial inequality.

The absence of whiteness, coupled with a minimization of discrimination, serves to blame those who are the victims of structural racism. Thus, colorblind ideology powerfully works to silence arguments for material equity and protects a conservative political and economic system. The pervasiveness of color blindness among both African Americans and Latinas/os shows the vast reach and productive power of this racial ideology to prevent oppositional thinking and promote complacency. In addition, it impedes racial and class alliances that are seen as irrelevant in a society that is about individual opportunity via hard work.

\section{Conclusion}

As stated earlier, our data were collected several years ago. Initially, we considered this a problem, as the information is not the most recent. We realized, however, that this particular data set not only provides a valuable window into Brown/Black relations in a particular time and place, but also helps us understand interethnic relations today by allowing a comparison of attitudes. Clearly, our data do not match the hostility and anger that the media present as the norm among Latinas/os and African Americans today. ${ }^{50}$ This is, no doubt, a function of sensationalistic journalism, but may also indicate a real change. In particular, our data collection preceded two major shifts in Los Angeles: first, the election of Antonio Villaraigosa as mayor, and second, growing Black antiimmigrant sentiment.

Villaraigosa was the first elected Latino mayor of Los Angeles in well over a century. When Villaraigosa first ran in 2001 against James Hahn, he lost. In particular, he fared poorly with older African Americans, but very well with young Black voters. In 2005, he won. Thus, Black and Brown Angelenos were living under a Latino mayor for essentially the first time. While for Latinas/os, especially ethnic Mexicans, his election is seen as major progress and an affirmation of political power, some African Americans are fearful and resentful of Latina/o political power. ${ }^{51}$ And while Villaraigosa has certainly reached out to African Americans, it is true that the number of Black elected officials is rapidly dwindling in California. Thus, it is uncertain how the presence of a Latino mayor may be affecting Black/Brown relations.

The second major change is the development of an incipient Black anti-immigrant movement in Southern California. Although few in number and supported by white, anti-immigrant organizations such as the Federation for 
American Immigration Reform (FAIR), Black Angelenos have voiced their opposition to undocumented immigration, immigrants, and Latinos/as in general, in increasingly vocal and hostile terms. This current has been led by Ted Hayes, a former homelessness activist, who created the Crispus Attucks Brigade and has declared immigration to be the single greatest threat to Black people since slavery. ${ }^{52}$ While many African Americans are critical of Hayes, he has created the political space for Black Angelenos to express growing hostility. Moreover, his outspokenness has been a blessing to anti-immigrant forces, as his Blackness serves to deflect charges of racism leveled against them. In today's racial logic, anti-immigrant groups supposedly cannot be racist if Black people support them. Thus, regardless of intent, a small but visible segment of African Americans is casting its lot with whites in direct opposition to the Brown working class.

While it is beyond the scope of this article to ascertain why these shifts have occurred, they illustrate the fluid nature of interethnic relations and the extent to which they are influenced by larger events. Such levels of Black animosity toward Latinas/os as those expressed by Hayes and his sympathizers simply did not exist among our interviewees.

What appears to be more historically resilient in our data is the anti-Black racism that exists on the part of some Latinas/os. While there are many possible reasons for this, one factor, which is directly linked to racial formation processes, is the evolving and ambiguous nature of Latina/o racial identity. While some researchers have argued that Latinas/os are moving toward whiteness, census data indicate that they are increasingly identifying as something other than white. Thus, it does not appear that Latinas/os are simply clamoring to be white, but it does appear that they are clamoring to be something other than Black. Does this mean Latinas/os are anti-Black? While some scholars, such as Rochmes and Griffin believe so, we do not. As descendants of colonized people, Latinas/os, especially the Mexican and Central American populations (which dominate in Southern California), must confront the task of reconciling their indigenous, Asian, African, and European roots. ${ }^{53}$ Moreover, they must do so within the context of overcoming the Black/white binary, which has historically rendered them invisible. Consciously identifying as Brown, Mexican, moreno, or mestizo is not necessarily anti-Black, but it may very well be, if it is aligned with whiteness.

In contemporary Los Angeles, Black people are being subordinated through the particularities of each group's racialization. The racialization of Black Angelenos as lazy and violent is directly opposed to the racialization of whites as hardworking and virtuous. In this discussion, Latinas/os are aligned with whiteness, as a racial formation, as Rochmes and Griffin have argued, while Blacks occupy a subordinate position. ${ }^{54}$ Although Latinas/os may not be white, 
their racialization as hard workers does the work of maintaining white supremacy, especially when compared to "lazy Blacks," enabling whiteness to go unchallenged. By adopting these ideals, Black and Brown people help perpetuate the racial order by objectifying themselves as agents of white supremacy.

In the end, our data clearly show that people of color are maintaining white supremacy. White supremacy is upheld in multiple ways, including, for example, the inability to speak its name and a lack of historical knowledge among Blacks and Latinos about each other. The notion that Latinas/os are new to Los Angeles and the idea that slavery ended with no consequences are just two instances of how Black and Latina/o Angelenos are unaware of each other's histories. Not knowing how different groups have been exploited and marginalized throughout history and into the contemporary period works in tandem with the notion that we live in a meritocracy and precludes either group from seeing how they are complicit in contributing to the oppression of other people of color. ${ }^{55}$ By focusing on meritocracy, we indirectly assert that neither past injustices nor our current actions have any bearing on current social conditions. Consequently, without a shared understanding of the ways in which African Americans and Latinas/os have been similarly exploited, the likelihood of coalition building is diminished. While there is a clear need for political organizing and consciousness-raising at the grassroots level, there is an equally important need for rigorous ethnic studies focusing on Black and Latina/o histories and racial dynamics.

Previous research, as well as our findings, has confirmed that higher levels of education are associated with greater racial tolerance and acceptance. ${ }^{56}$ This is a complicated argument, as we do not wish to imply that workingclass people are more racist than elites. But one important difference between the two is the fact that the middle class is more educated and has had the opportunity to learn about, for example, Black history. Though ethnic studies exists in higher education, this does not address the problem, as relatively few African Americans and Latinas/os attend college. What we really need to focus on is K-12 ethnic studies and popular education to reach the non-college population. One example is the Southern California Library for Social Studies and Research in South Los Angeles. The library has brought together local Brown and Black youth to research their neighborhoods' histories and link them to larger racial, economic, and cultural patterns. These are avenues that can reach many people and begin to counteract the logics of color-blind ideology. By knowing each other's history, African Americans and Latinas/os will be slower to minimize the significance of discrimination, because of a better grasp of how past and current institutional practices operate to subordinate people of color. History can highlight the ways that whiteness has remained illusive and unchallenged, while at the same time allowing 
Latinas/os and Black people to understand their structural relationships to one another.

Obviously, a critical, popular education will not automatically translate into solidarity, yet we suggest that it is extremely hard to get there without a historical context. We do not ignore the very real material ways in which Blacks and Browns feel that they are competing for resources. Nor do we ignore that Black anti-Latina/o and Latina/o anti-Black prejudices exist. But we do believe that a return to the foundations of ethnic studies-popular education and community organizing - can together help alleviate interethnic tensions among people of color by providing an alternative framework in which to view their differences.

\section{NOTES}

1. Albert Camarillo, "Cities of Color: The New Racial Frontier in California's MinorityMajority Cities," Pacific Historical Review 76, no. 1 (2007): 1-28.

2. Chrisshonna Grant Nieva, "Racialized Representations in the Los Angeles Times" (unpublished manuscript, University of Southern California, 2009).

3. Tatcho Mindiola Jr., Yolanda Flores Niemann, and Nestor Rodriguez, Black-Brown Relations and Stereotypes (Austin: University of Texas Press, 2002); Paula McClain et al., "Racial Distancing in a Southern City: Latino Immigrants' Views of Black Americans," Journal of Politics 68, no. 3 (2006): 571-584; Bryan Jackson, Elisabeth Gerber, and Bruce Cain, "Coalitional Prospects in a Multi-racial Society: African-American Attitudes toward Other Minority Groups," Political Research Quarterly 47, no. 2 (1994): 277-294; and Mark Sawyer, "Myths and Realities: Black and Brown Politics in Los Angeles" (unpublished manuscript, Center for the Study of Race, Ethnicity, and Politics, University of California, Los Angeles, 2010).

4. John Betancur and Douglas Gills, The Collaborative City: Opportunities and Struggles for Blacks and Latinos in U.S. Cities (New York: Garland Publishing, 2000); Frank Bonilla and Walter Stafford, "African Americans and Puerto Ricans in New York: Cycles and Circles of Discrimination," in Collaborative City, 42-58; Edward Chang and Jeannette Diaz-Veizades, Ethnic Peace in the American City: Building Community in Los Angeles and Beyond (New York: New York University Press, 1999); Paula McClain and Joseph Stewart, Can We All Get Along? Racial and Ethnic Minorities in American Politics (Boulder, CO: Westview Press, 1998); Rebecca Morales and Manual Pastor, "Can't We All Just Get Along? Interethnic Organization for Economic Development," in Collaborative City, 157-176.

5. For work on how immigration has been described as a key factor in conflict among communities of color, see John Betancur, "Framing the Discussion of African American-Latino Relations: A Review and Analysis," in Neither Enemies Nor Friends: Latinos, Blacks, and Afro-Latinos, ed. Anani Dzidzienyo and Suzanne Oboler (New York: Palgrave Macmillan, 2005), 159-172; Keith Jennings and Clarence Lusane, "The State and Future of Black/Latino Relations in Washington, DC: A Bridge in Need of Repair," in Blacks, Latinos, and Asians in Urban America, ed. James Jennings (Westport, CT: Praeger, 1994), 57-78; James Johnson and Melvin Oliver, "Interethnic Minority Conflict in Urban America: The Effects of Economic and Social Dislocations," rpt. in Race and Ethnic Conflict, ed. Fred Pincus and Howard Ehrlich (Boulder, CO: Westview Press, 1994), 194-205; Manning Marable, "Building Coalitions among Communities of Color: Beyond Racial Identity Politics," in Blacks, Latinos, and Asians in Urban America, 29-44; Nestor Rodriguez, "The Real New World Order: The Globalization of Racial and Ethnic Relations in the Late Twentieth Century," in The Bubbling Cauldron: Race, Ethnicity, and the Urban Crisis, ed. Michael Smith and Joe Feagin (Minneapolis: University of 
Minnesota Press, 1995), 211-225; and Nestor Rodriguez, "U.S. Immigration and Intergroup Relations in the Late 20th Century: African Americans and Latinos," in Immigration: A Civil Rights Issue for the Americas, ed. Susanne Jonas and Suzanne Thomas (Wilmington, DE: Scholarly Resources, 1999), 131-144. For examples on economic and job competition, see Betancur, "Framing the Discussion," 159-172; Jennings and Lusane, "State and Future," 57-78; Johnson and Oliver, "Interethnic Minority Conflict," 194-205; Rodriguez, "Real New World Order," 211-225. For studies on the conflict over political representation, see Albert Camarillo, "Black and Brown in Compton: Demographic Change, Suburban Decline, and Intergroup Relations in a South Central Los Angeles Community, 1950 to 2000," in Not Just Black and White: Historical and Contemporary Perspectives on Immigration, Race, and Ethnicity in the United States (New York: Russell Sage Foundation, 2004), 358-376; Jennings and Lusane, "State and Future," 57-78; James Johnson, Walter Farrell, and Chandra Guinn, "Immigration Reform and the Browning of America: Tensions, Conflicts and Community Instability in Metropolitan Los Angeles," International Migration Review 31, no. 4 (1997): 1055-1095; and Paula McClain and Steven Tauber, "Black and Latino Socioeconomic and Political Competition: Has a Decade Made a Difference?" American Politics Quarterly 26, no. 2 (1998): 237-252. For a discussion on the impact of conflicts over material resources, see Jennings and Lusane, "State and Future," 57-78, and McClain and Tauber, "Black and Latino," 237-252.

6. McClain and Stewart, Can We All Get Along?, 145.

7. For examples, see Nicolas Vaca, "The Folly of Presumption" and "Passed By and Shut Out," in The Presumed Alliance: The Unspoken Conflict between Latinos and Blacks and What It Means for America (New York: Harper, 2004), 85-107 and 108-126; and Cedric Herring et al., Empowerment in Chicago: Grassroots Participation in Economic Development and Poverty Alleviation (Chicago: University of Illinois Press, 1998). Mark Sawyer, however, found that African Americans in Los Angeles were more likely to see Latinas/os as potential coalition partners, while Barreto, Gonzalez, and Sanchez found that Latinas/os in California are more likely to see African Americans as partners than in other parts of the United States. Sawyer, "Myths and Realities," 22; Matt Barreto, Benjamin Gonzalez, and Gabriel Sanchez, "Rainbow Coalition in the Golden State? Exposing Myths, Uncovering New Realities in Latino Attitudes towards Blacks," in Black and Brown in Los Angeles: Beyond Conflict and Coalition, ed. Josh Kun and Laura Pulido (Berkeley: University of California Press, 2013), 203-232.

8. For Blacks' perception of Latino immigration as a threat, see Johnson and Oliver, "Interethnic Minority Conflict," 194-205; Melvin Oliver and James Johnson, "Inter-Ethnic Conflict in an Urban Ghetto: The Case of Blacks and Latinos in Los Angeles," Research in Social Movements, Conflict, and Change 6 (1984): 57-94; and Tatcho Mindiola, Nestor Rodriguez, and Yolanda Niemann, Intergroup Relations between Hispanics and Blacks in Harris County (Houston: University of Houston, Center for Mexican American Studies, 1996). For Black antipathy toward the Spanish language, see Betancur, "Framing the Discussion," 159-172, and Johnson and Oliver, "Interethnic Minority Conflict," 194-205. For work on the perception that an immigrants' rights agenda displaces that of Civil Rights, see Luis Guevera, Dallas in Transition: The Politics of Hispanics and African Americans in the 1990s (Claremont, CA: Tomas Rivera Policy Institute, 1996), and Johnson and Oliver, "Interethnic Minority Conflict," 194-205. For a discussion of Latinos' negative perceptions of Blacks, see James Johnson and Melvin Oliver, "Interethnic Minority Conflict in Urban America: The Effects of Economic and Social Dislocations," Urban Geography 10, no. 5 (1989): 449-463; and Wallace Lambert and Donald Taylor, Coping with Cultural and Racial Diversity in Urban America (New York: Praeger, 1990).

9. Johnson and Oliver, "Interethnic Minority Conflict," 194-205; Mindiola et al., Intergroup Relations; Paula McClain, "Racial Distancing in a Southern City: Latino Immigrants" Views of Black Americans," Journal of Politics 68, no. 3 (2006): 571-584; Alejandro Portes and Alex Stepick, City on the Edge: The Transformation of Miami (Berkeley: University of California Press, 1993). 
10. For general attitudes in Los Angeles, see Johnson and Oliver, "Interethnic Minority Conflict," 194-205; James Johnson, Walter Farrell, and Chandra Guinn, "Immigration Reform and the Browning of America: Conflicts and Community Instability in Metropolitan Los Angeles," International Migration Review 31 (1997): 1055-1095; Mark Sawyer, "Myths and Realities," 12, 14; and Barreto et al., "Rainbow Coalition in the Golden State?"

11. On potential coalition partners, see Mark Sawyer, "Myths and Realities," 22; Barreto et al., "Rainbow Coalition in the Golden State?"; and Manuel Pastor and Enrico Marcelli, "Somewhere over the Rainbow? African Americans, Unauthorized Mexican Immigration, and Coalition Building," in The Impact of Immigration on African Americans, ed. Steven Shulman (New Brunswick: Transaction Publishers, 2004). On points of conflict, see J. Eric Oliver and Janelle Wong, "Intergroup Prejudice in Multiethnic Settings," American Journal of Political Science 47, no. 4 (2003): 567-582; David Sears, "Assessment of Interracial/Interethnic Conflict in Los Angeles" (Center for Research in Society and Politics, UCLA, 2002); and Mark Sawyer, "Myths and Reality," 12, 14, 16, 19. See also J. Eric Oliver and Tali Mendelberg, "Reconsidering the Environmental Determinants of White Racial Attitudes," American Journal of Political Science 44, no. 3 (2000): 574-589.

12. On the similarities between Black and white views on immigration, see Mark Sawyer, "Myths and Realities," 11, and Lawrence Bobo and Vincent L. Hutchings, "Perceptions of Racial Group Competition: Extending Blumer's Theory of Group Position to a Multiracial Social Context," American Sociological Review 61 (1996): 963. On African American attitudes toward very specific immigration issues, see Lorrie Frasure and Stacey Greene, "Inter-group Relations, Neighborhood Context and African American Views toward Undocumented Immigration," forthcoming in The Black and Brown Reader, ed. Josh Kun and Laura Pulido (Berkeley: University of California Press). For a more general analysis of these views, see Claudine Gay, "Your Blues Ain't Like Mine: The Effect of Economic Disparity on Black Attitudes towards Latinos" (paper presented at the annual meeting of the American Political Science Association, Washington, DC, 2005). For data arguing that more mixed neighborhoods actually lead to more tolerance, see Oliver and Wong, "Intergroup Prejudice," 567-582.

13. For some important exceptions, see Tomás Almaguer, "Race, Nationality and the Conundrums of Latinidad" (paper presented at "Racial Formation in the Twenty-First Century," a symposium held at the University of Oregon, April 17, 2009); Nicholas De Genova and Ana Rayos-Zamos, Latino Crossings: Mexicans, Puerto Ricans, and the Politics of Race and Citizenship (New York: Routledge, 2003); and Daniel Rochmes and G. A. Elmer Griffin, "The Cactus That Must Not Be Mistaken for a Pillow: White Racial Formation among Latinos," Souls 8, no. 2 (2006): 77-91.

14. For a full critique, see Eduardo Bonilla-Silva and Tukufu Zuberi, White Logic, White Methods (Lanham, MD: Rowman and Littlefield, 2008).

15. Unfortunately, their approach to Latinas/os and whiteness is rather simplistic, taking census figures at face value. For a critique of Latinos and the census, see Clara Rodriguez, Changing Race: Latinos, the Census, and the History of Ethnicity in the United States (New York: New York University Press, 2000).

16. Nicholas De Genova and Ana Y. Ramos-Zayas, Latino Crossings: Mexicans, Puerto Ricans, and the Politics of Race and Citizenship (New York: Routledge, 2003), and Almaguer, "Race, Nationality and the Conundrums of Latinidad."

17. While color-blind ideology remains one of the dominant tropes used to maintain white supremacy, other contemporary tropes, such as multiracialism and multiculturalism, have also gained growing influence as key American racial ideologies. See, for example, Michael Brown et al., Whitewashing Race: The Myth of a Color-Blind Society (Berkeley: University of California Press, 2002); Antonia Dader and Rodolfo Torres, After Race: Racism after Multiculturalism (New York: New York University Press, 2004); and Jared Sexton, Amalgamation Schemes: Antiblackness and the Critique of Multiracialism (Minneapolis: University of Minnesota Press, 2008). 
18. Neil Gotanda, "A Critique of 'Our Constitution Is Color-Blind,'” Stanford Law Review 44, no. 1 (1997): 2.

19. Eduardo Bonilla-Silva, Racism without Racists: Color-Blind Racism and the Persistence of Racial Inequality in the United States (Lanham, MD: Rowman and Littlefield, 2003), 3.

20. For abstract liberalism, see ibid., 28-31; for naturalism, see ibid., 37; for cultural racism, see ibid., 28; and for minimization, see ibid., 29.

21. Kimberlé Crenshaw, "Color Blindness, History, and the Law," in The House That Race Built, ed. Wahneema Lubiano (New York: Vintage Books, 1998), 281.

22. Ashley Doane, "Rethinking Whiteness Studies," in White Out: The Continuing Significance of Racism, ed. Ashley Doane and Eduardo Bonilla-Silva (New York: Routledge, 2003), 13.

23. See, for example, Daniel HoSang, Racial Proposition: Genteel Apartheid in Postwar California (Berkeley: University of California Press, forthcoming).

24. Pulido, Black, Brown, Yellow, and Left; George Lipsitz, "The Racialization of Space and the Spatialization of Race," Landscape Journal 26, no. 1 (2007): 10-23.

25. For instances of connection, see Gaye Johnson, "Constellations of Struggle: Luisa Moreno, Charlotta Bass, and the Legacy for Ethnic Studies," Aztlán: A Journal of Chicano Studies 33, no. 1 (2008): 155-172; Anthony Macias, Mexican American Mojo: Popular Music, Dance, and Urban Culture in Los Angeles, 1935-1968 (Durham, NC: Duke University Press, 2008); and Pulido, Black, Brown, Yellow, and Left, chap. 5.

26. Although Africans Americans came for jobs, they were initially excluded from defense manufacturing. See Scott Kurashige, The Shifting Grounds of Race (Princeton, NJ: Princeton University Press, 2008), chap. 6, and Kevin Allen Leonard, "Years of Hope, Days of Fear: The Impact of World War II on Race Relations in Los Angeles" (Ph.D. diss., University of California, Davis, 1992). On the concern of Black Angelenos over new arrivals, see Lawrence De Graff, “The City of Black Angels: Emergence of the Los Angeles Ghetto, 1890-1930," Pacific Historical Review 39 (1970): 323-352.

27. Los Angeles Alliance for a New Economy, Poverty, Jobs and the Los Angeles Economy (Los Angeles: LAANE, 2007), 6.

28. Manuel Pastor, "Keeping it Real: Demographic Change, Economic Conflict, and Inter-Ethnic Organizing for Social Justice in Los Angeles," Black and Brown Reader, 12.

29. Indeed, competition for private sector jobs has been a source of conflict at times. See Vaca, The Presumed Alliance, 51-61; Jerry Yaffe, "Institutional and Racial Barriers to Employment Equity for Hispanics," Hispanic Journal of Behavioral Sciences 16, no. 3 (1994): 211-229; and Paula McClain, "The Changing Dynamics of Urban Politics: Black and Hispanic Municipal Employment-Is There Competition?” Journal of Politics 55, no. 2 (1993): 399-414.

30. It is important to note that this racial imbalance is usually exaggerated. Cynthia Cranford found that in 1970 African Americans constituted 48 percent of Los Angeles janitors, Latinas/os 13 percent, and whites most of the remainder. By 1990 Black janitors were 14 percent of the workforce. "Economic Restructuring, Immigration and the New Labor Movement: Latina/o Janitors in Los Angeles" (San Diego: Center for Comparative Immigration Studies, University of California, San Diego, 2000), 7-8. See also Service Employees International Union, "A Penny for Justice: Janitors and L.A.'s Commercial Real Estate Market" (Los Angeles: SEIU Local 399, March 1995).

31. Paul Ong and Abel Valenzuela, "The Labor Market: Immigrant Effects and Racial Disparities," in Ethnic Los Angeles, ed. Roger Waldinger and Mehdi Bozorgmehr (New York: Russell Sage Foundation, 1996), 175.

32. Josh Sides notes that "the preference of industrial employers for Mexican over black workers-especially in the metal and food industries-had become thoroughly entrenched" by the 1960s. L.A. City Limits: African American Los Angeles from the Great Depression to the Present (Berkeley: University of California Press, 2006), 94. See also Pulido, Black, Brown, Yellow, and Left, chap. 2.

33. On employer preferences for Latina/o workers, see Gregory Acs and Pamela Loprest, "Working for Cents on the Dollar: Race and Ethnic Wage Gaps in the Noncollege Labor Mar- 
ket," Low-Income Working Families, Paper 13 (Washington, DC: The Urban Institute, 2009), 7; Joleen Kirschenman and Kathryn Neckerman, "WW'd Love to Hire Them, But . . .': The Meaning of Race for Employers," in The Urban Underclass, ed. Christopher Jencks and Paul Peterson (Washington, DC: Brookings Institution, 1991), 203-232; Philip Moss and Chris Tilly, Stories Employers Tell: Race, Skill, and Hiring in America (New York: Russell Sage Foundation, 2001); and Roger Waldinger and Michael Lichter, How the Other Half Works: Immigration and the Social Organization of Labor (Berkeley: University of California Press, 2003), chap. 9. On contemporary workplace organizing, see Ruth Milkman, Organizing Immigrants: The Challenge for Unions in Contemporary California (Ithaca, NY: Cornell University Press, 2000).

34. According to Manuel Pastor, Los Angeles County lost 41.4 percent of its manufacturing jobs between 1990 and 2005. Durable manufacturing dropped by 10 percent, while nondurable rose by 10 percent. "Keeping It Real," 12.

35. On regional economic shifts, see Melvin Oliver, James Johnson, and William Farrell, "Anatomy of a Rebellion," in Reading Rodney King, Reading Urban Uprising, ed. Robert Gooding-Williams (New York: Routledge, 1993), 117-141. On the working poor, see Los Angeles for a New Economy, The Other Los Angeles: The Working Poor in the City of the 21st Century (Los Angeles: LAANE, August 2000).

36. Ruth Wilson Gilmore, The Golden Gulag: Prisons, Surplus, Crisis, and Opposition in Globalizing California (Berkeley: University of California Press, 2007).

37. For a detailed examination of changing residential patterns, see James Allen and Eugene Turner, The Ethnic Quilt: Population Diversity in Southern California (Northridge: Center for Geographical Studies, California State University Northridge, 1997).

38. On contact theory among people of color, see Eric Oliver and Janelle Wong, "Intergroup Prejudice," 567-582.

39. This finding corroborates with Mark Sawyer's observation that Black Angelenos over assumed the "illegality" of Latinas/os. "Myths and Reality," 16.

40. For work on slavery in Latin America, see Darien Davis, Slavery and Beyond: The African Impact on Latin America and the Caribbean (Wilmington, DE: Scholarly Resources, 1994); David Etlis, The Rise of African Slavery in the Americas (Cambridge: Cambridge University Press, 2000); Herbert Klein and Ben Vinson III, African Slavery in Latin America and the Caribbean (Oxford: Oxford University Press, 2007); Jane Landers and Barry Robinson, Slaves, Subjects, and Subversives: Blacks in Colonial Latin America (Albuquerque: University of New Mexico Press, 2006); and Martha Menchaca, Recovering History, Constructing Race: Indian, Black, and White Roots of Mexican Americans (Austin: University of Texas Press, 2001).

41. On the nature of white privilege itself, see George Lipsitz, The Possessive Investment in Whiteness: How White People Profit from Identity Politics (Philadelphia: Temple University Press, 1998). For discussions of how Mexican Americans may have profited from the subordination of other people of color, see Laura Gómez, Manifest Destinies: The Making of the Mexican American Race (New York: New York University Press, 2007); and Thomas Guglielmo, "Fighting for Caucasian Rights: Mexicans, Mexican Americans, and the Transnational Struggle for Civil Rights in World War II Texas," Journal of American History 92, no. 4 (2006): 1212-1237.

42. Although popular understandings of Latina/o racial subjectivity position them as nonwhite, in fact, 80 percent of Cubans identify as white-the highest of any Latina/o group. John Logan, How Race Counts for Hispanic Americans (Albany: Lewis Mumford Center, State University of New York, 2003), 4.

43. Yolanda Niemann, Andrea Romero, Jorge Arredondo, and Victor Rodriguez, "What Does It Mean To Be Mexican? Social Construction of an Ethnic Identity," Hispanic Journal of Behavioral Sciences 21, no. 1 (1999): 47-60; Tatcho Mindiola, Yolanda Flores Niemann, and Néstor Rodriguez, "Stereotypes and Their Implications for Intergroup Relations," BlackBrown Relations and Stereotypes, 19-42.

44. For recent attacks on Latina/o immigration, see Leo Chavez, The Latino Threat: Con- 
structing Immigrants, Citizens, and the Nation (Stanford: Stanford University Press, 2008), and Laura Pulido, "Immigration Politics and Motherhood," Amerasia 35, no. 1 (2009): 169178.

45. Although it is beyond the scope of this article, it is worth noting that "Daniel" identified as Latino, rather than Black, despite being both. On Black Latinas/os, see Anani Dzidzienyo and Suzanne Oboler, Neither Enemies nor Friends.

46. Neil Gotanda, "A Critique," 6.

47. Bonilla-Silva found that although Black respondents had adopted many dominant racial attitudes (but certainly not all, especially regarding discrimination), he did not consider them to be participants in color-blind ideology because they did not participate in whites' racial semantics. Racism without Racists, chap. 5 .

48. Interestingly, Mark Sawyer found that Black Angelenos exhibited by far the highest rates of union support among all Angelenos. Thus, it is possible that this support for labor unions is also associated with a particular wage. "Myths and Realities," 10.

49. The literature of Black organizing is vast. A few examples include Robin Kelley, Hammer and Hoe: Alabama Communists during the Great Depression (Chapel Hill: University of North Carolina Press, 1990); Michael Denning, The Cultural Front (London: Verso, 1997); George Lipsitz, A Life in the Struggle: Ivory Perry and the Culture of Opposition (Philadelphia: Temple University Press, 1988); Nelson Perry, Black Fire: The Making of an American Revolutionary (New York: New Press, 1994); and William Harris, Keeping the Faith (Urbana: University of Illinois Press, 1991).

50. An earlier study indicates even more positive attitudes. See Jackson et al., "Coalitional Prospects in a Multi-racial Society."

51. On voting patterns, see Dowell Myers, "Probing the Demographic Depth of Villaraigosa's Mayoral Victory: Shifting Weights and Preferences" (unpublished manuscript, School of Social Policy, Planning and Development, University of Southern California, 2005). On municipal elections and electoral politics more generally, see Paula McClain, "Presidential Address. 'Racial Intergroup Relations in a Set of Cities: A Twenty-Year Perspective," Journal of Politics 68, no. 4 (2006): 757-770. Indeed, Jackson et al. argue that Black Angelenos had such positive views of Latinas/os in the 1990s precisely because Los Angeles had a Black mayor for two decades. "Coalitional Prospects in a Multi-racial Society," 283.

52. On Ted Hayes, see Chrisshonna Grant Nieva, "Black on Both Sides: The Use of Blackness in the Latino Immigration Debate," Black and Brown Reader, and the Crispus Attucks Brigade website, accessed July 1, 2009, http://tedhayes.us/uscab. For an example of a Black Angeleno who agrees with Hayes, see Theodore Smith III, Letter to the Editor, Los Angeles Times, April 28, 2006, B12. For African Americans who are in solidarity with Latina/o immigrants, see the Black Alliance for Just Immigration website, accessed June 23, 2009, http:// blackalliance.org.

53. For work on Latinas/os seeking whiteness, see Carleen Basler, "White Dreams and Red Votes: Mexican Americans and the Lure of Inclusion in the Republican Party," Ethnic and Racial Studies 31, no. 1 (2008): 123-166; Neil Foley, "Becoming Hispanic: Mexican Americans and the Faustian Pact with Whiteness," in Reflexiones: New Directions in Mexican American Studies, ed. Neil Foley (Austin: Center for Mexican American Studies, 1997), 53-70; Laura Gómez, Manifest Destinies; Thomas Guglielmo, "A Critical Moment"; and Rochmes and Griffin, "The Cactus That Must Not Be Mistaken for a Pillow." For work on the racial middle, see Eileen O'Brien, The Racial Middle: Latinos and Asian Americans Living beyond the Racial Divide (New York: New York University Press, 2008); Jonathan Warren and France Winddance, "White Americans: The New Minority? Non-Blacks and the Ever-Expanding Boundaries of Whiteness," Journal of Black Studies 28, no. 2 (1997): 200-218; and George Yancey, Who is White? Latinos, Asians, and the New Black/NonBlack Divide (Boulder, CO: Lynne Rienner, 2003). For evidence of Latinas/os not identifying as white, see John Logan, How Race Counts for Hispanic Americans (Albany, New York: Lewis Mumford Center, 2003), and Sonya Tafoya, Shades of Belonging (Washington, DC: Pew Hispanic Center, 2004). For work on immigrants 
distancing themselves from African American identity for social acceptance, see Mary Waters, Black Identities: West Indian Immigrant Dreams and American Realities (Cambridge, MA: Harvard University Press, 1999).

54. Rochmes and Griffin, "The Cactus That Must Not Be Mistaken for a Pillow."

55. For a theoretical analysis of how people of color are complicit in each other's oppression, see Andrea Smith, "Indigeneity/Settler Colonialism/White Supremacy" (unpublished manuscript, University of California, Riverside, 2010).

56. Kenneth Meier, Paula McClain, J. L. Plinard, and Robert Wrinkle, "Divided or Together?': Conflict and Cooperation between African Americans and Latinos," Political Research Quarterly 57, no. 3 (2004): 399-409. 